\title{
Streamflow—Water Year 2018
}

\section{Introduction}

The maps and graphs in this summary describe national streamflow conditions for water year 2018 (October 1, 2017 , to September 30, 2018) in the context of streamflow ranks relative to the 89-year period of water years 1930-2018, unless otherwise noted. The illustrations are based on observed data from the U.S. Geological Survey (USGS) National Streamflow Network (U.S. Geological Survey, 2019a). The period of water years 1930-2018 was used because the number of streamgages before 1930 is too small to provide representative data for computing statistics for most regions of the country.

In the summary, reference is made to the term "runoff," which is defined here as the amount of water flowing through a stream divided by the drainage basin area of the stream. The value of runoff quantifies the magnitude of water flowing through the Nation's rivers and streams in measurement units that can be compared from one area to another. In this summary, runoff for a specified period and geographic area is computed from all streamgages with complete streamflow record in the geographic area.

In all the graphics, a rank of 1 indicates the highest annual flow of all years analyzed and 89 indicates the lowest annual flow of all years. Rankings of streamflow are grouped into much below normal, below normal, normal, above normal, and much above normal based on percentiles of flow (less than 10 percent, 10-24 percent, 25-75 percent, 76-90 percent, and greater than 90 percent, respectively; U.S. Geological Survey, 2019b). Streamflow conditions for States or water-resources regions are presented in the text in order of ranking from highest flow to lowest flow; a highest or lowest flow rank is not shown when there are ties in the rankings. Some of the data used to produce the maps and graphs are provisional and subject to change.

\section{National Overview}

Annual runoff in the Nation's rivers and streams during water year 2018 (9.82 inches; fig. 1) was higher than the long-term (water years 1930-2018) mean annual runoff of 9.33 inches. Nationwide, the 2018 streamflow ranked 33d highest out of the 89 years.

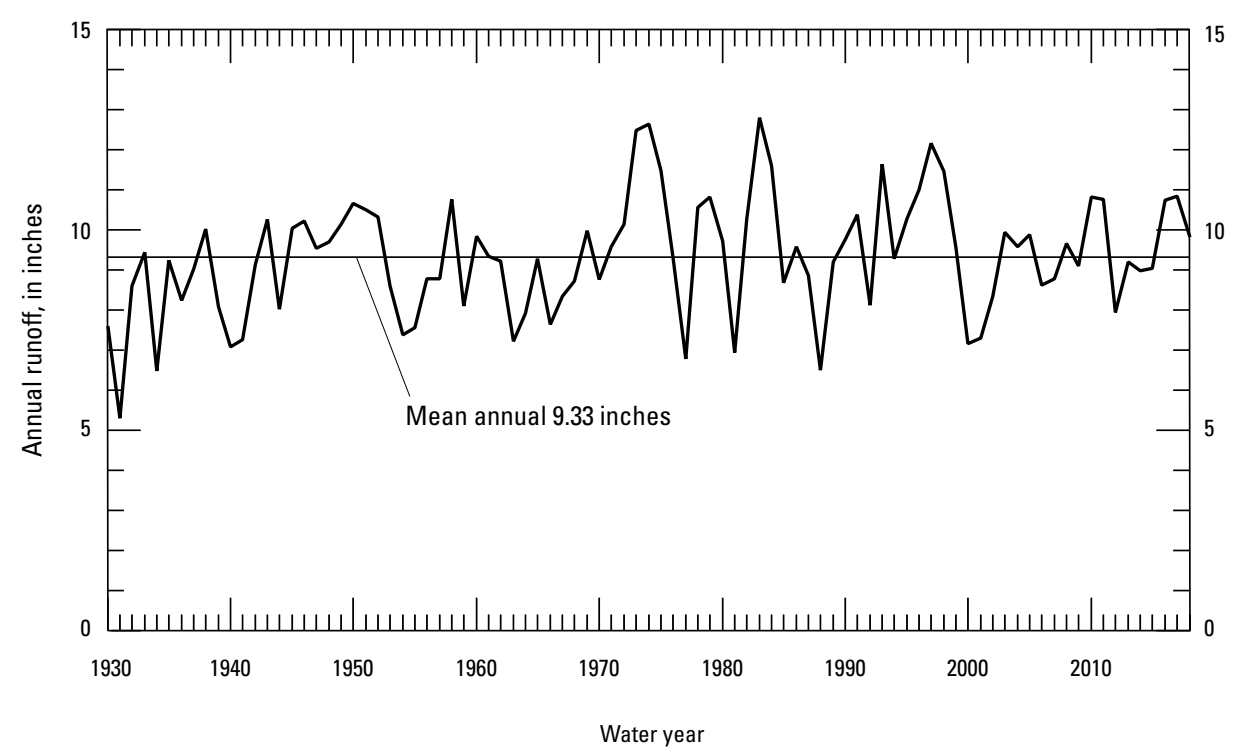

Figure 1. Annual runoff in the United States, water years 1930-2018. 
Record low streamflow levels were reported in Arizona (fig. 2). Streamflow was much below normal in Colorado and New Mexico. Streamflow was below normal in Utah, Alaska, Kansas, and Oregon. Streamflow was above normal in Delaware, North Carolina, Nebraska, Wyoming, Tennessee, Indiana, Minnesota, District of Columbia, Kentucky, and South Dakota. Streamflow was much above normal in Iowa, Michigan, Maryland, Wisconsin, West Virginia, Ohio, Montana, and Pennsylvania. Half of the States had streamflow in the normal range.

\section{Regional Patterns}

The United States, Puerto Rico, and the Virgin Islands are divided into 21 large drainages, or water-resources regions (fig. 3). These waterresources regions are based on surface topography and contain the drainage area of a major river; the combined drainage areas of a series of rivers, such as the Texas-Gulf region, which includes several rivers draining into the Gulf of Mexico; or the area of an island or island group. Water-resources regions provide a coherent, watershed-based framework for depicting streamflow variations.

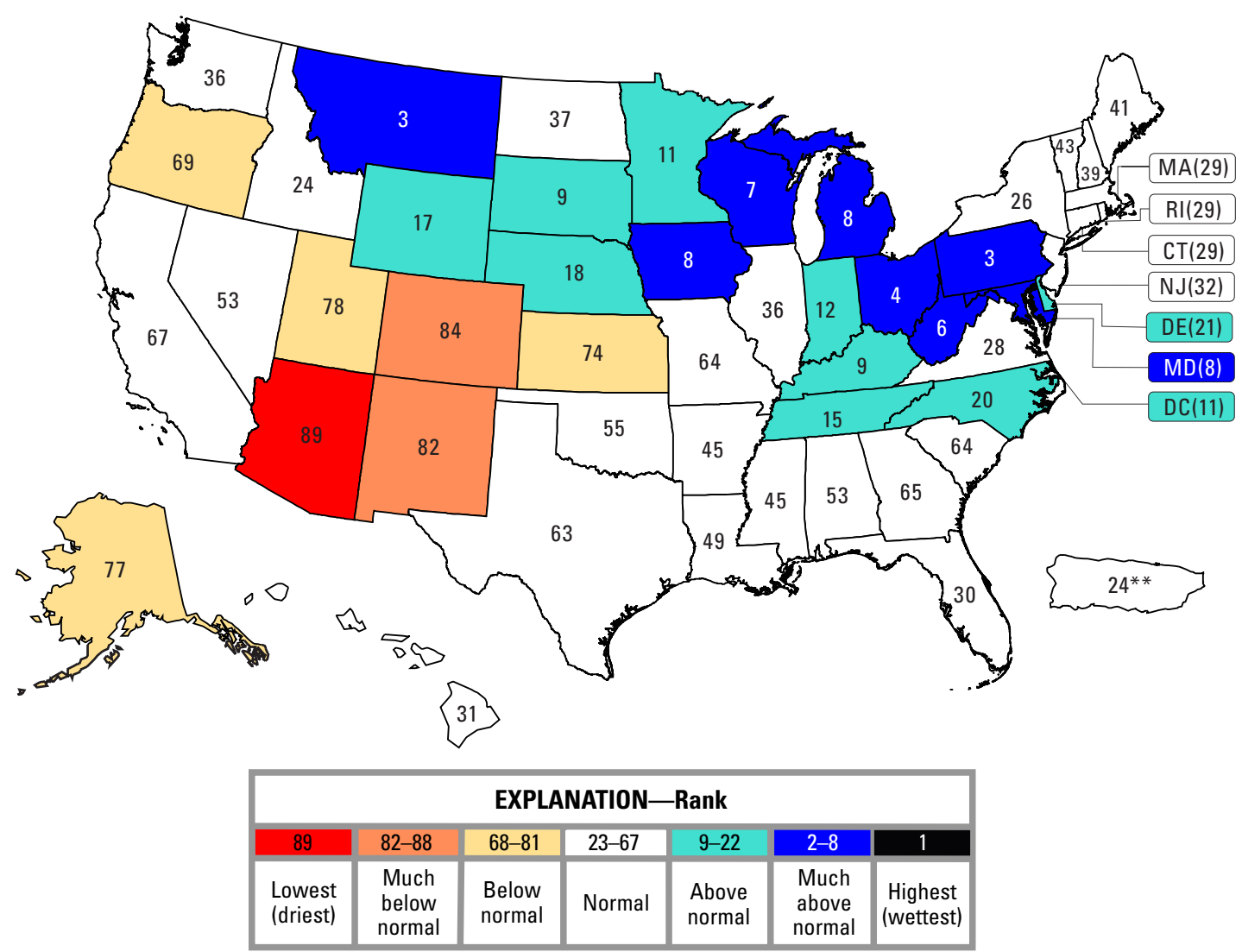

Figure 2. Statewide streamflow ranks of the United States for water year 2018 relative to mean annual streamflow for water years 1930-2018. [**For Puerto Rico and the Virgin Islands, 75 years of available data were used and the groupings of ranks were adjusted accordingly.]

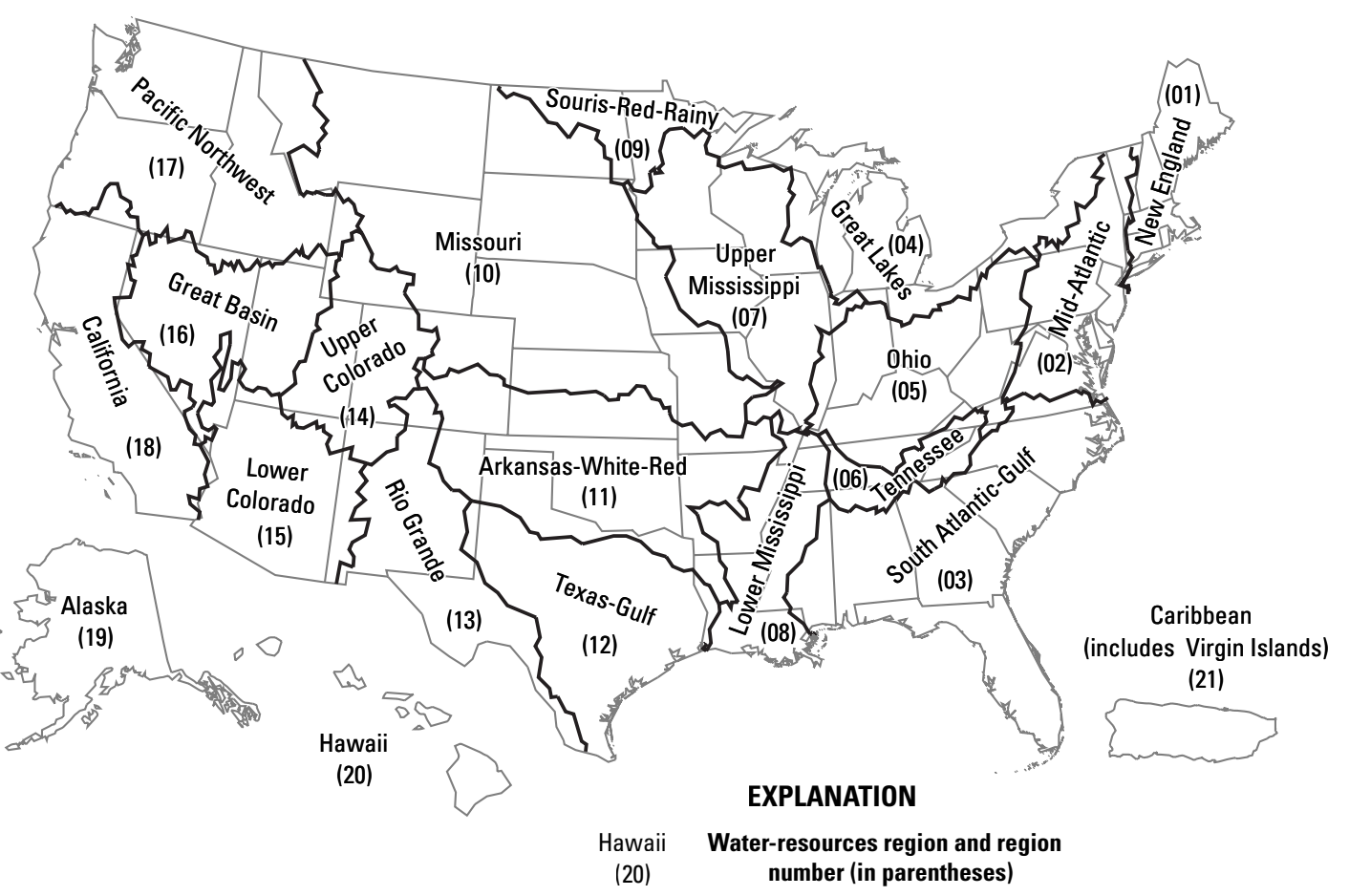

Figure 3. Water-resources regions. 
Streamflow was reported at much below normal levels in the Lower Colorado region (fig. 4). Below normal streamflow was reported in the Upper Colorado, Rio Grande, Alaska, and California regions. Streamflow was above normal in the Tennessee, Upper Mississippi, Great Lakes, and Mid-Atlantic regions. Much above normal streamflow was reported in the Ohio region.

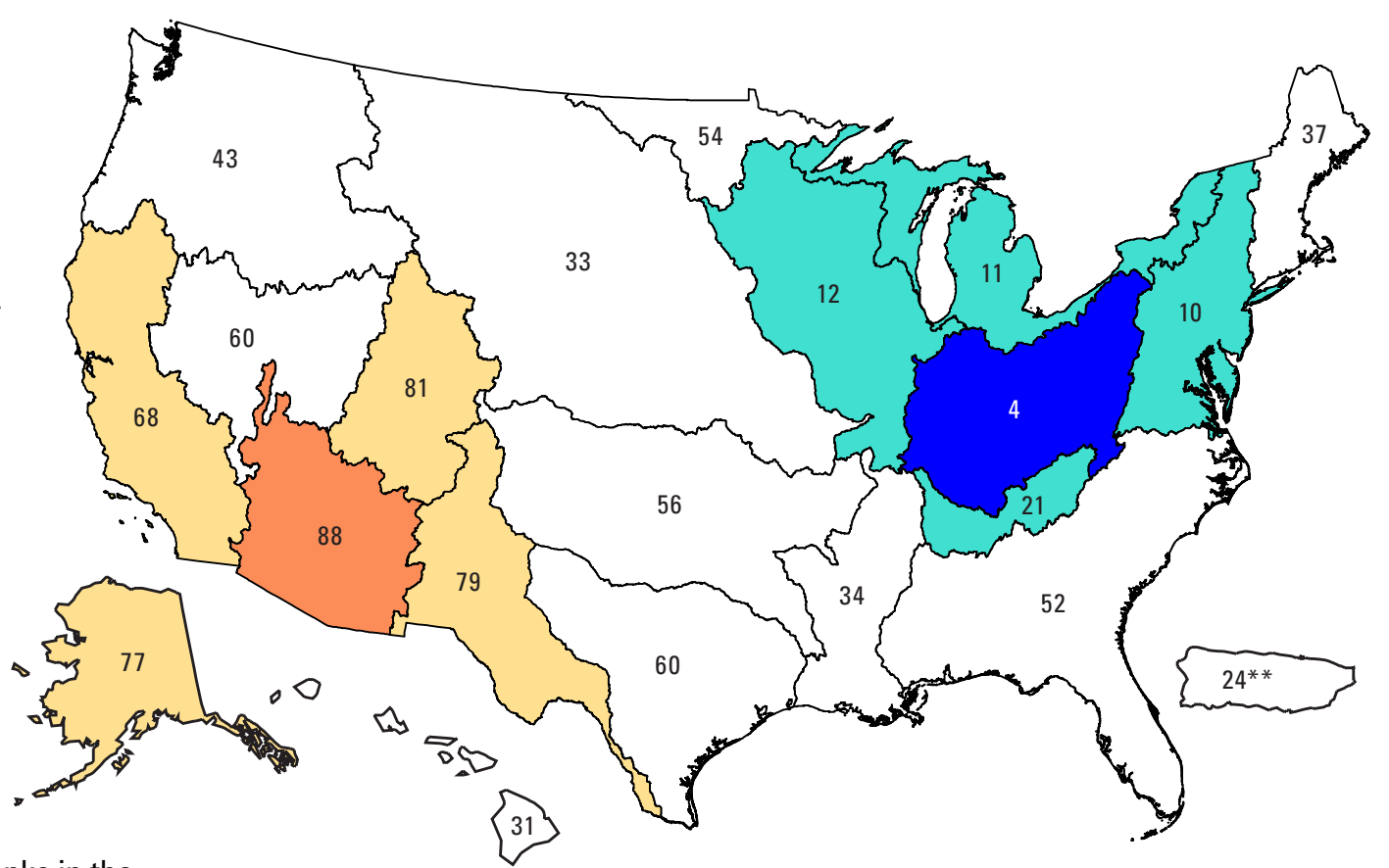

Figure 4. Regional streamflow ranks in the United States for water year 2018 relative to mean annual streamflow for water years 1930-2018. [**For Puerto Rico and the Virgin Islands, 75 years of available data were used and the groupings of ranks were adjusted accordingly.]

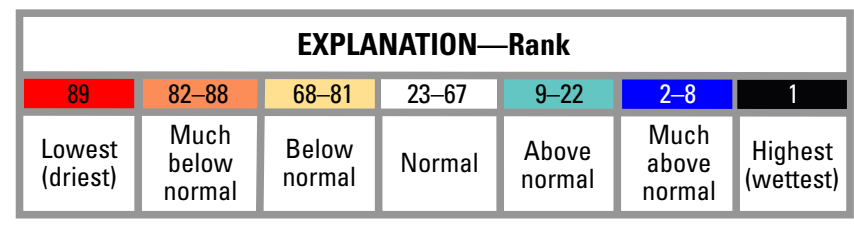

\section{Seasonal Characteristics}

For the autumn season (October-December 2017), streamflow was much below normal in Arizona (fig. 5). Streamflow was below normal in New Jersey, Virginia, Arkansas, Louisiana, South Carolina, District of Columbia, Maryland, North Carolina, and Texas. Above normal streamflow was reported in Montana, Idaho, Wisconsin, New Mexico, and Florida. Much above normal streamflow was reported in Minnesota, South Dakota, Michigan, Wyoming, Puerto Rico and the Virgin Islands, and Nebraska. Streamflows were reported at record high levels in Nevada. Nationwide, autumn-season streamflow ranked 53d highest out of 89 years.
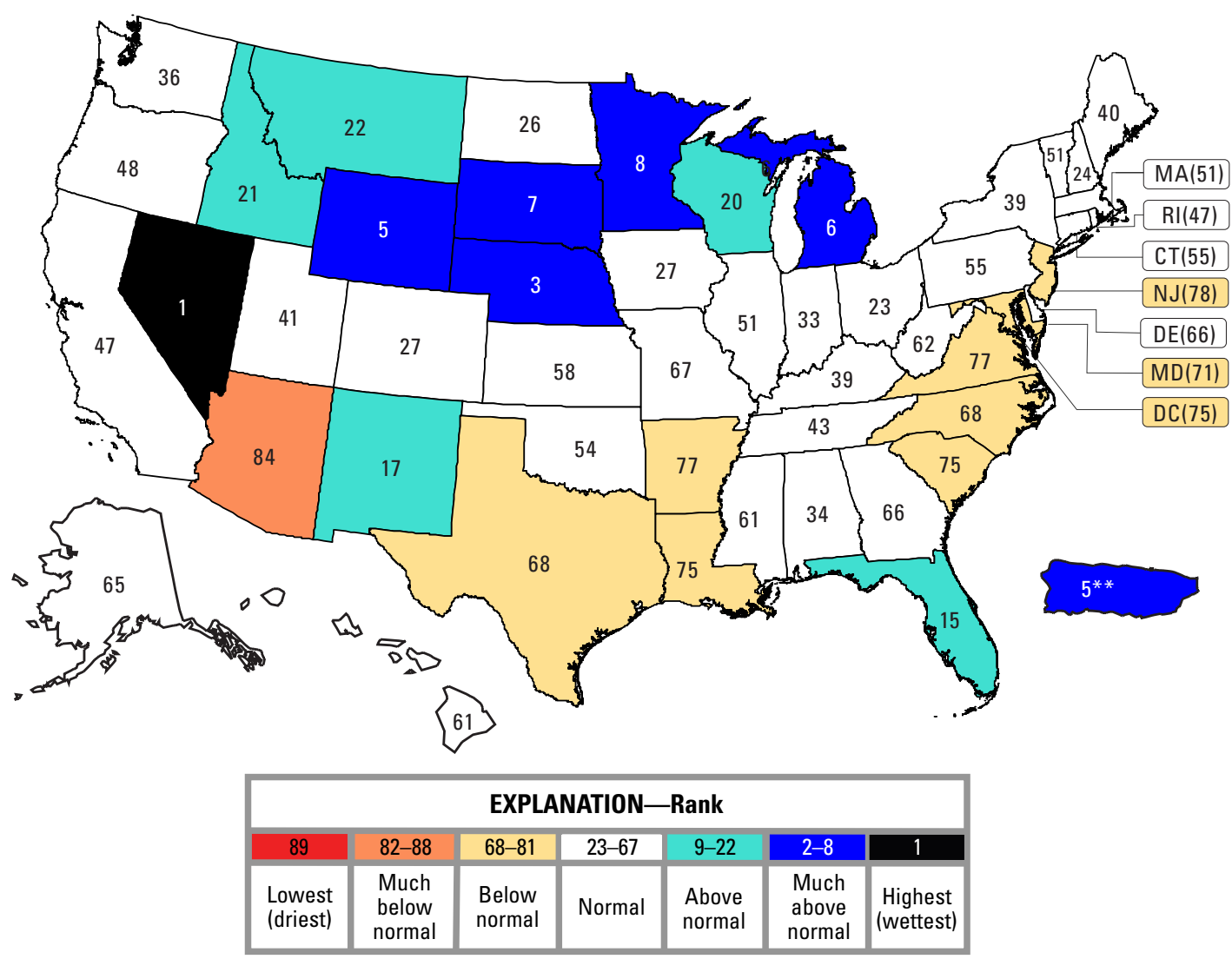

Figure 5. Autumn (October-December 2017) statewide ranks in the United States relative to mean annual streamflow for water years 1930-2018. [**For Puerto Rico and the Virgin Islands, 75 years of available data were used and the groupings of ranks were adjusted accordingly.] 
For the winter season (January-March 2018), streamflow was at a record low in Arizona (fig. 6). Streamflow was below normal in South Carolina, Georgia, New Mexico, District of Columbia, Florida, Alaska, and North Carolina. Above normal streamflow was reported in Michigan, Connecticut, Tennessee, Vermont, South Dakota, West Virginia, Indiana, Arkansas, Maine, Kentucky, Idaho, New York, Pennsylvania, New Hampshire, Massachusetts, Puerto Rico and the Virgin Islands, Ohio, and Wyoming.

Streamflow was much above normal in Montana, Rhode Island, and Nevada. Nationwide, winter-season streamflow ranked 37th highest out of 89 years.

For the spring season (April-June 2018), streamflow was much below normal in Arizona, New Mexico, Colorado, Utah, and Kansas (fig. 7). Below normal streamflow was reported in Texas, Oklahoma, and New Hampshire. Above normal streamflow was reported in Florida, New Jersey, Iowa, Nevada, South Dakota, Wisconsin, Hawaii, Tennessee, Pennsylvania, North Carolina, Wyoming, and Ohio. Streamflow was much above normal in Delaware, District of Columbia, Virginia, Maryland, West Virginia, and Montana. Nationwide, spring-season streamflow ranked 34th highest out of 89 years.

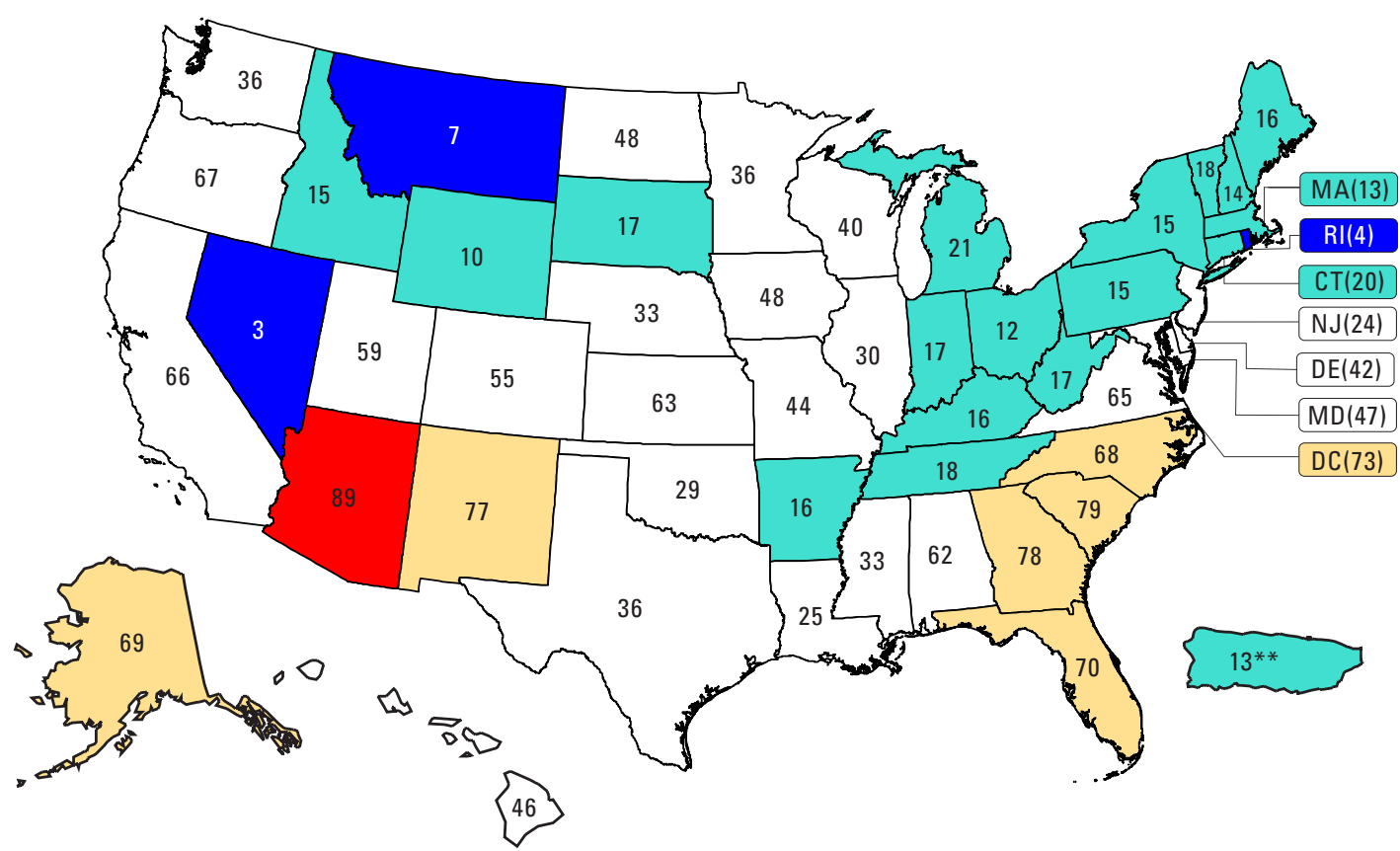

\begin{tabular}{|c|c|c|c|c|c|c|}
\hline \multicolumn{7}{|c|}{ EXPLANATION_Rank } \\
\hline 89 & $82-88$ & 68-81 & 23-67 & $9-22$ & $2-8$ & 1 \\
\hline $\begin{array}{l}\text { Lowest } \\
\text { (driest) }\end{array}$ & $\begin{array}{l}\text { Much } \\
\text { below } \\
\text { normal }\end{array}$ & $\begin{array}{l}\text { Below } \\
\text { normal }\end{array}$ & Normal & $\begin{array}{l}\text { Above } \\
\text { normal }\end{array}$ & $\begin{array}{l}\text { Much } \\
\text { above } \\
\text { normal }\end{array}$ & $\begin{array}{c}\text { Highest } \\
\text { (wettest) }\end{array}$ \\
\hline
\end{tabular}

Figure 6. Winter (January-March 2018) statewide ranks in the United States relative to mean annual streamflow for water years 1930-2018. [**For Puerto Rico and the Virgin Islands, 75 years of available data were used and the groupings of ranks were adjusted accordingly.]

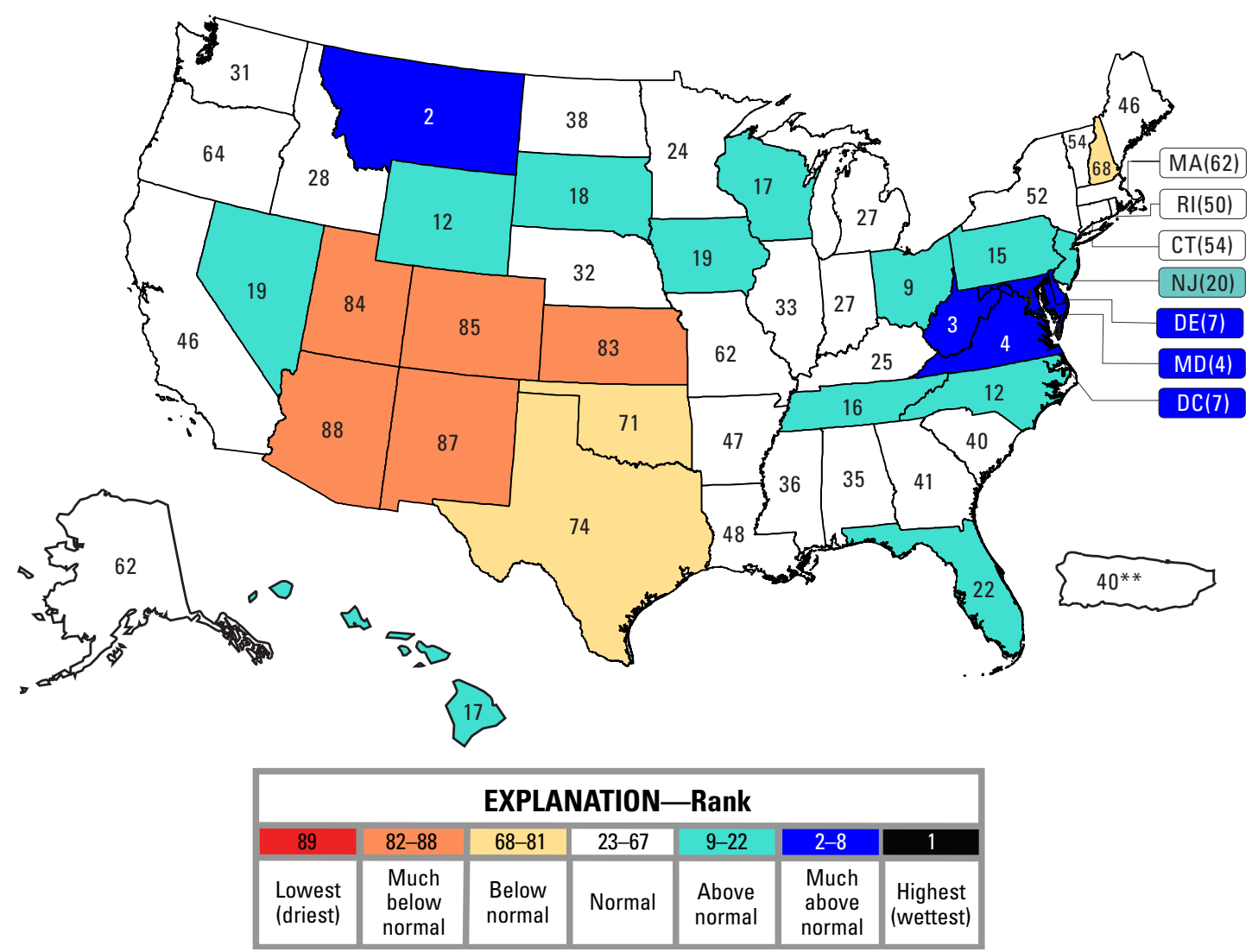

Figure 7. Spring (April-June 2018) statewide ranks in the United States relative to mean annual streamflow for water years 1930-2018. [ **For Puerto Rico and the Virgin Islands, 75 years of available data were used and the groupings of ranks were adjusted accordingly.] 
For the summer season (July-September 2018), streamflow was much below normal in Colorado, New Mexico, Arizona, Maine, and Alaska (fig. 8). Below normal streamflow was reported in Washington, Utah, and Oregon. Above normal streamflow was observed in Michigan, South Carolina, Oklahoma, Tennessee, New Hampshire, New York, Illinois, Hawaii, Ohio, New Jersey, Delaware, and Indiana. Much above normal streamflow was reported in Nebraska, Wisconsin, Massachusetts, Minnesota, Virginia, Connecticut, Kentucky, South Dakota, Iowa, and West Virginia. Record high streamflow was reported in North Carolina, Pennsylvania, District of Columbia, and Maryland. Nationwide, summer-season streamflow ranked $3 \mathrm{~d}$ highest out of 89 years.

\section{High and Low Flows}

Assuming that individual streamgages act independently of each other, it is expected that the mean streamflow at 5 percent of the streamgages will be high (greater than the 95th percentile) and 5 percent will be low (less than the 5th percentile) in any given month. The percentages of streamgages reporting high streamflow in 5 months of water year 2018 (October 2017 and February, May, August, and September 2018) were higher than expected $(6,11,9$, 9 , and 18 percent, respectively; fig. 9). In contrast, there was only one month (June 2018) with a greater-than-expected percentage of streamgages with low flows ( 6 percent).

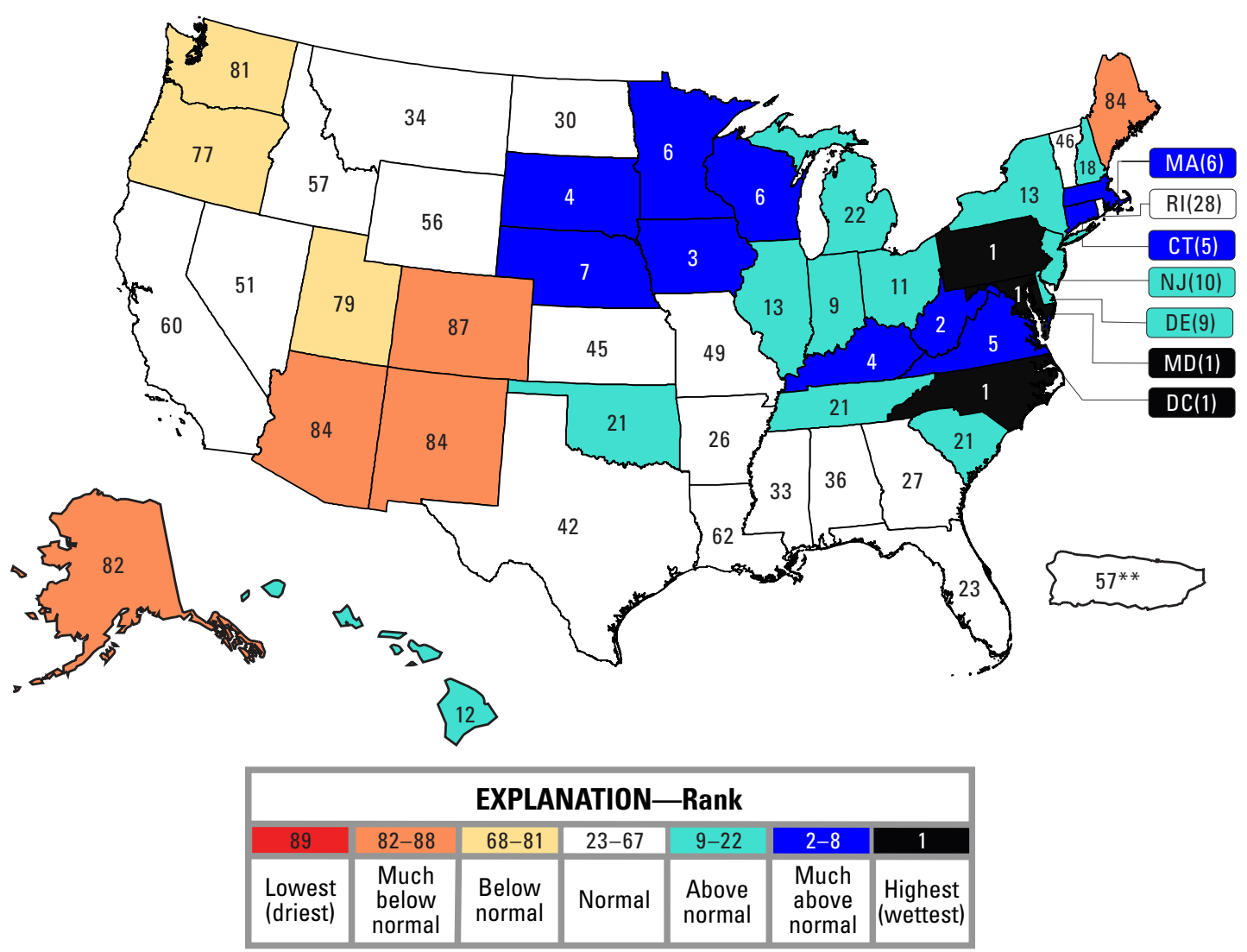

Figure 8. Summer (July-September 2018) statewide ranks in the United States relative to mean annual streamflow for water years 1930-2018. [**For Puerto Rico and the Virgin Islands, 75 years of available data were used and the groupings of ranks were adjusted accordingly.]

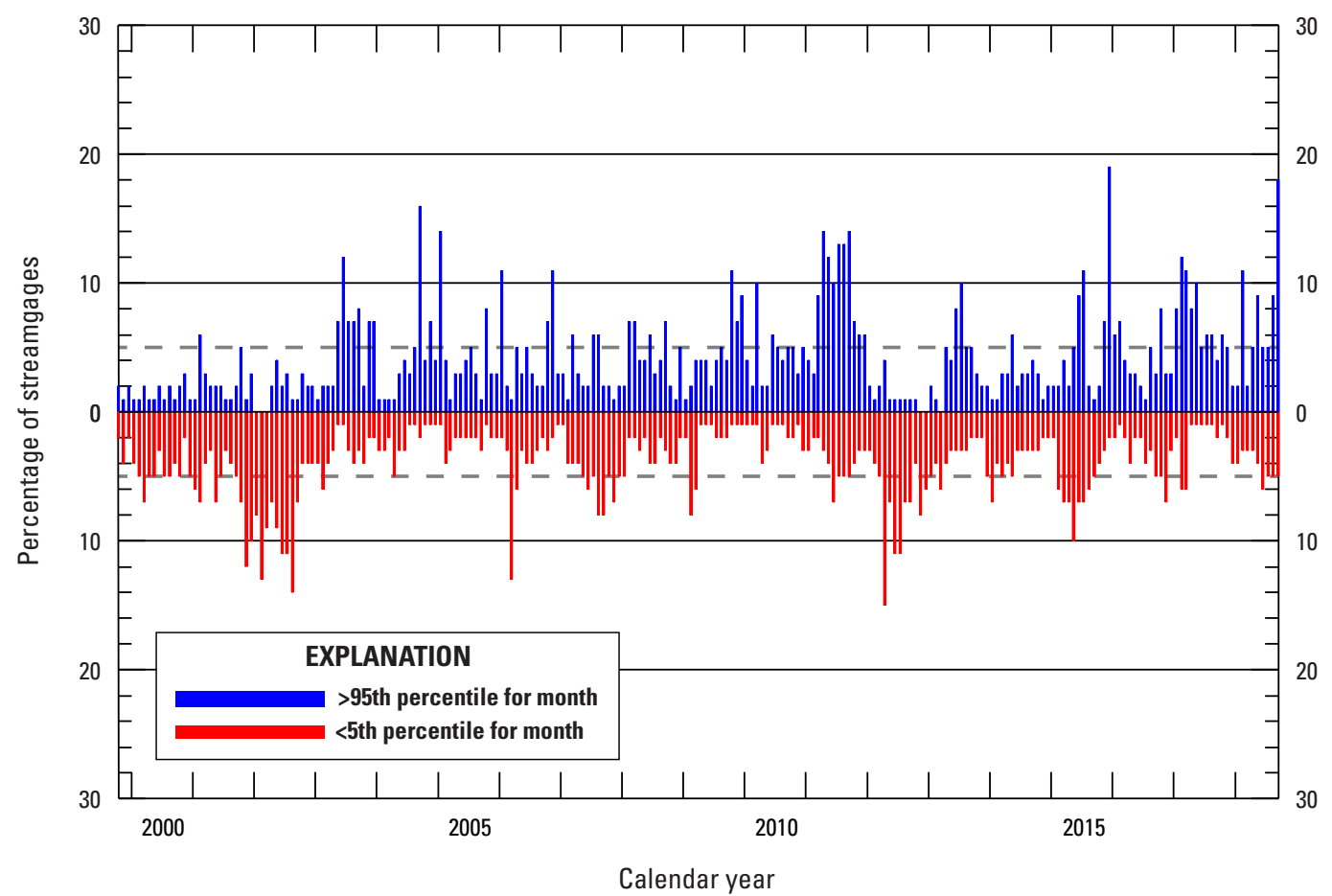

Figure 9. Percentage of streamgages with monthly streamflow greater than the 95th percentile (in blue) or less than the 5th percentile (in red), October 1999-September 2018. 


\section{Additional Information}

The USGS operated a nationwide network of more than 8,200 streamgages in 2018, and almost all USGS streamgages are operated in real time. Current information derived from these streamgages is available at https:// waterwatch.usgs.gov. Tables of data that summarize historical streamflow conditions by State, expressed as runoff, beginning in water year 1901, can be accessed at https://waterwatch.usgs.gov/?id=statesum. These tables are updated every few months to reflect the most current streamflow data.

The streamflow information used to prepare this summary also is used for water management, flood and drought monitoring, bridge design, and several recreational activities. To obtain real-time and archived streamflow data and information, visit the USGS National Water Information System at https://doi.org/10.5066/F7P55KJN (U.S. Geological Survey, 2019c). The National Streamflow Network, which is part of the Groundwater and Streamflow Information Program, is operated primarily by the USGS; however, funding for operating the network is provided by the USGS and about 850 Federal, State, Tribal, regional, and local partners. Access additional streamflow information online at https://www.usgs.gov/ water-resources/groundwater-and-streamflow-information/ streamflow-monitoring?qt-science_support_page_related_ con=0\#qt-science_support_page_related_con.

\section{References}

U.S. Geological Survey, 2019a, Groundwater and Streamflow Information Program: U.S. Geological Survey web page, accessed July 2019 at https://www.usgs.gov/water-resources/ groundwater-and-streamflow-information.

U.S. Geological Survey, 2019b, Map of real-time streamflow compared to historical streamflow for the day of the year (United States): U.S. Geological Survey web page, accessed July 2019 at https://waterwatch.usgs.gov/?id=ww_current.

U.S. Geological Survey, 2019c, USGS water data for the Nation: U.S. Geological Survey National Water Information System database, accessed September 30, 2019, at https://doi. org/10.5066/F7P55KJN.

By Xiaodong Jian, David M. Wolock, Steven J. Brady, and Harry F. Lins

\section{For additional information, contact:}
U.S. Geological Survey
415 National Center
Reston, VA 20192
https://water.usgs.gov/

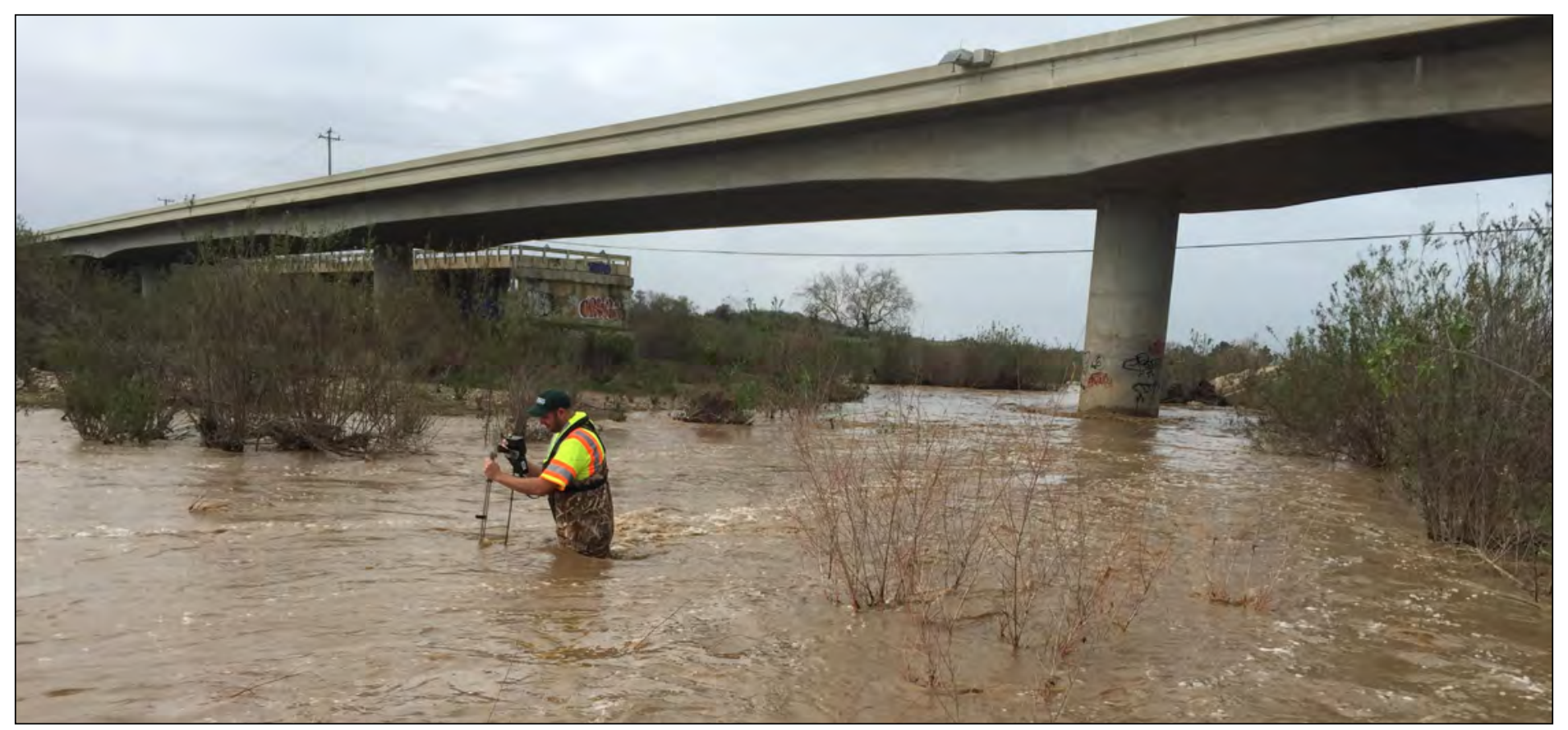

Photograph showing U.S. Geological Survey technician measuring streamflow in the Sisquoc River near Garey, California, upstream from the Santa Maria Mesa Road Bridge. Photograph taken in 2017 by U.S. Geological Survey. 